Keith M. Carlson

Keith $M$. Carlson is an assistant vice president at the Federal Reserve Bank of St. Louis. Thomas A. Pollmann provided research assistance.

\title{
On the Macroeconomics of Private Debt
}

$\mathbf{E}$ Chip forecasters indicated that the most important factor influencing the outlook for near-term economic growth in the United States was the debt burden carried by governments, households and businesses. ${ }^{1}$ Debt and borrowing are common features of economic life, yet not everyone agrees on their role in the economy because borrowing can be viewed either positively or negatively. It is considered prudent to borfow to take advantage of an investment opportunity, but it is considered unwise to borrow simply so that you can consume beyond your means. Consequently, concerns about debt can arise when credit is not available, as well as when it is too readily available. In this sense, debt is a lot like money; it can cause problems when it grows too slowly, as well as when it grows too rapidly.

The current concern in the United States, however, is that the volume of debt has built up so much that it is a drag on spending, thereby dampening the economic recovery. ${ }^{2}$ Such a concern applies to all economic units, both private and public. But to limit the discussion here, the focus is private debt-that is, the accumulation of past and present borrowing by house-

\footnotetext{
'See Blue Chip Economic Indicators (1992). For extensive documentation relating to the concerns of the U.S. news media with the size of the debt, both public and private, see McKenzie and Klein (1992).

2This was the theme of Chairman Greenspan's testimony before Congress on February 19, 1992. For a discussion of similar concerns in other industrial countries, see Intema. tional Monetary Fund (1992).
}

More specifically, the discusston is restricted to the private domestic nonfinancial sector, thereby disregarding the bor- holds and private (nonfinancial) business. ${ }^{3}$ During the recent recession, the term balance sheet restructuring has been used to describe the process of businesses and households adjusting their assets and liabilities along with their spending and saving in an effort to lighten debt loads.

The focus of this article is the role of private nonfinancial debt in the economy. Some perspective will be provided on debt's growth, magnitude and composition, along with some explanations of why these trends have occurred and additional consideration of their economic effects. The question of when and why debt becomes a burden is also addressed.

\section{DEBT TWENTS IN PERSPECTIVE}

Figure 1 illustrates the basis for recent concern about the burden of debt as it relates to the private nonfinancial sector. In figure 1 the major categories of private debt are expressed relative to gross domestic product (GDP). Debt is defined as credit market debt (at par value) owed by households and domestic nonfinancial businesses as presented in the Federal Reserve flow of funds. ${ }^{4}$

rowing by governments, financial institutions and fofeigners in U.S. credit markets.

4The main source of flow-ot-funds data is the Federal Reserve's $Z .1$ release. These releases are published quarterly and contain information on flows and outstanding debt There is also summary information published in the federal Reserve Bulletin. The household sector in the flow of funds also includes personal trusts and nonprofit organizations. 
Figure 1

Private Nonfinancial Debt as a Percent of Gross Domestic Product

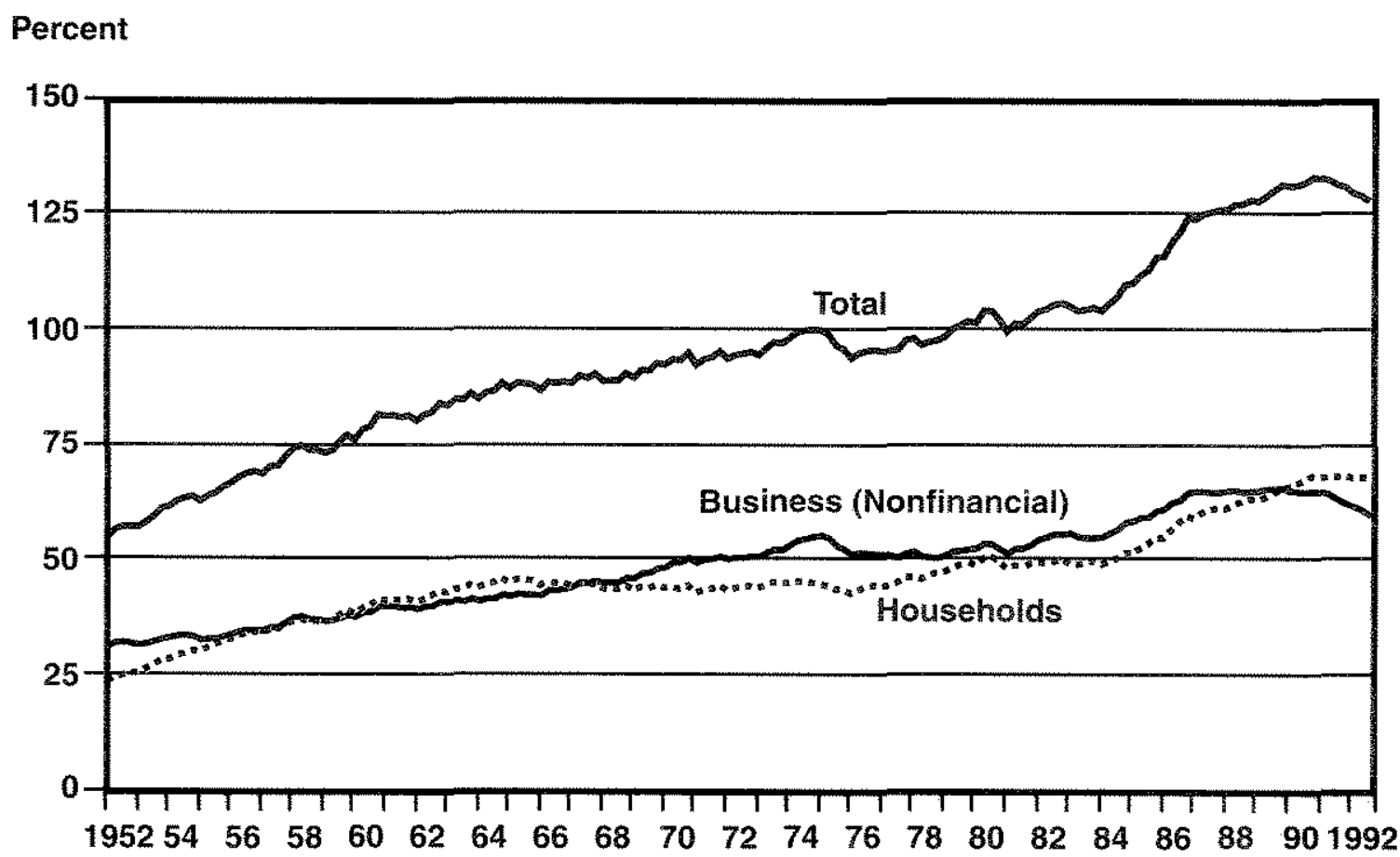

The amount of private nonfinancial debt in the economy, the top line in figure 1 , rose from 101 percent of GDP in 1981 to 132 percent in 1990 before declining in 1991. Debt of both sectors-households and businesses-rose substantialy during the 1980 s, although the patterns of growth were different. Of the 31-percentage. point increase in this debt/GDP ratio from 1981 to 1990 , the household sector accounted for 18 percentage points.

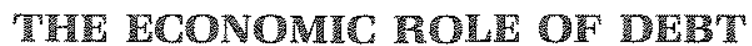

Being in debt is so common that the average person gives litle thought to the role of debt in the functioning of a free-market economy. Reasons for borrowing vary greatly among econom. ic units, but the way these diverse borrowers interact with lenders and exchange funds is what interests economists. Financial markets encompass all types of transactions involving flows of funds between borrowers and lenders or exchanges of existing debt.

\section{Functions of Debt}

Specific reasons to borrow, that is, to incur debt, are easy to enumerate. An individual, for example, might not be willing to wait to consume a certain product but rather is willing to sacrifice some future consumption to boost present consumption. Future consumption is sacrificed as the borrower makes interest pay. ments out of future income to a lender for the use of borrowed funds. Consumers borrow or lend to smooth consumption over ime. The purpose of this smoothing, in turn, is to maximize utility (or satisfaction) over the individuals lifetime.

Businesses borrow in an effort to maximize long-run profit. Businesses need to borrow short term for operational purposes, for example, to accumulate inventory to sell at a profit over time. They borrow long lerm to purchase capital assets that add to the productivity of the business and enhance profit over a long horizon. 
To the extent that debt increases consumer satisfaction over time, it is clear that debt is beneficial. The benefits of exchanging funds are similar to those that occur when individuals exchange goods and services, permitting specialization of labor and increasing the output for society as a whole. In the case of borrowing and lending funds, the payoff can be an enlarged stock of capttal goods, which allows for increased production and therefore increased consumption in the future. Financial markets bring those with surplus funds together with deficit units, thereby enabling the ultimate user to direct these funds to the accumulation of capital.

\section{The Market for Debt}

Economists refer to the market for debt as the market for loanable funds. The interaction of the suppliers and demanders of funds deter. mines the quantity of debt and its price, more commonly known as the interest rate. In reality, of course, the market is much more complex, involving many kinds of debt and many interest rates.

Debt markets can be classified in many ways. Most commonly these markets are classified by borrower-that is, demanders of funds, such as households, businesses and governments. A second way to look at debt markets is to group them by type of transaction, such as corporate bonds, bank loans, consumer credit and mortgage debt. Finally, it is helpful to know who the lenders are. In other words, where do the funds come from? The lender classification provides information about whether the transfer of funds is direct or indirect. In the early stages of a country's development, most transfers are direct-the lender and the borrower are making the exchange without any intermediary. ${ }^{\circ}$ As a country develops, intermediaries tend to evolve because they bring lenders and borrowers together at a lower cost than if the transactions were conducted directly.

Table 1 summarizes the U.S. credit market in terms of transactions, borrowers and lenders. The government, financial and foreign sectors are included in the table to illustrate the relative size of the domestic, private nonfinancial sector. Of total credit market debt outstanding at the end of 1991, households owed 27.8 per. cent and domestic nonfinancial businesses owed 25.4 percent. At the same time, households owned 12 percent of the credit market debt outstanding and domestic nonfinancial businesses owned 1.5 percent.

The dominant role of private financial institutions in the U.S. credit market is evidenced by the fact that they make 50 percent or more of the loans in each market except tax-exempt obligations. Private financial institutions own 61.9 percent of total credit market debt, whereas government-related financial institutions, for example, sponsored agencies, mortgage pools and the monetary authority, own 12.9 percent of the total.

For further discussion of the U.S. market for loanable funds, see the shaded insert on p. 58 .

\section{SOME QUESTIONS ABOUT PRIVATE DEBT}

The importance and significance of the growth and magnitude of private debt during the $1980 \mathrm{~s}$ is a matter of dispute. Most of the concern about private debt seems to be among journalists, whereas the number of economists express. ing concern is quite small. "The reasons for this discrepancy will be examined by trying to answer several questions. Discussion of these questions will not provide definitive answers, but hopefully they will shed light on whether there should be cause for concern about the buildup of private debt.

\section{Question 1: Why Did Debt Ratios Rise Rapidly in the 1980s?}

Figure 1 gave a summary picture of the growth of private debt as a percent of GDP. particularly in the $1980 \mathrm{~s}$. Most economists agree, however, that the ratio of debt to tangible assets is a more meaningful measure of solvency, of the ability to pay off a loan. The ratio of debt to GDP ignores the asset side of the balance sheet. Changes in the debt/asset ratio provide an indication of whether the net worth of an economic unit is increasing or decreasing.

Some insight into the use of debt/asset ratios can be obtained by looking at the growth rates of the components of the ratio. Table 2 gives a 
Table 1

\section{Credit Market Debt in 1991: Who Owes and Who Owns?}

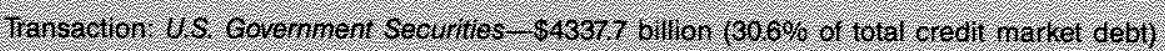

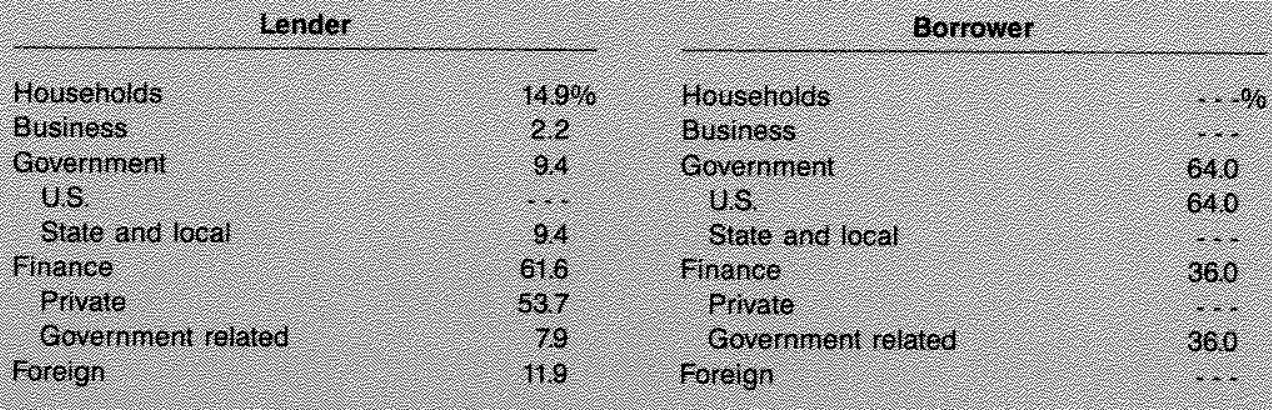

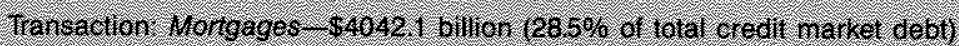

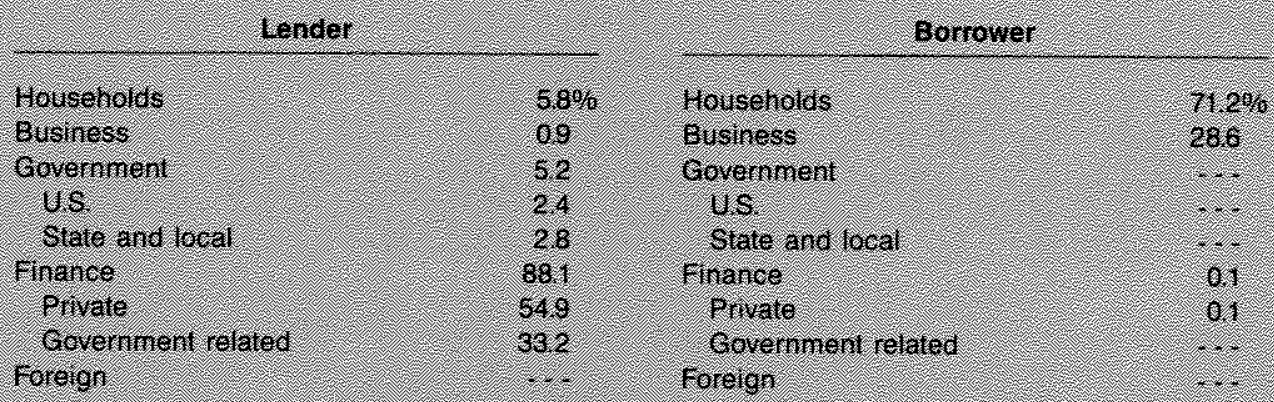

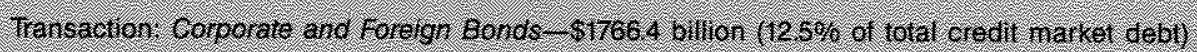

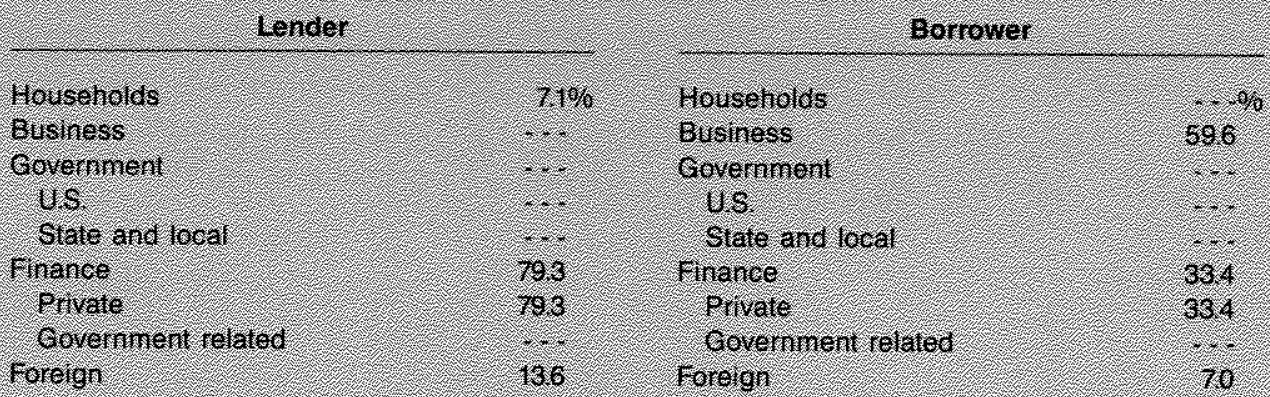

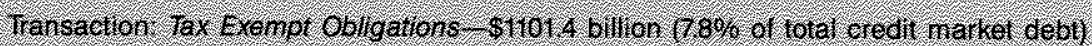

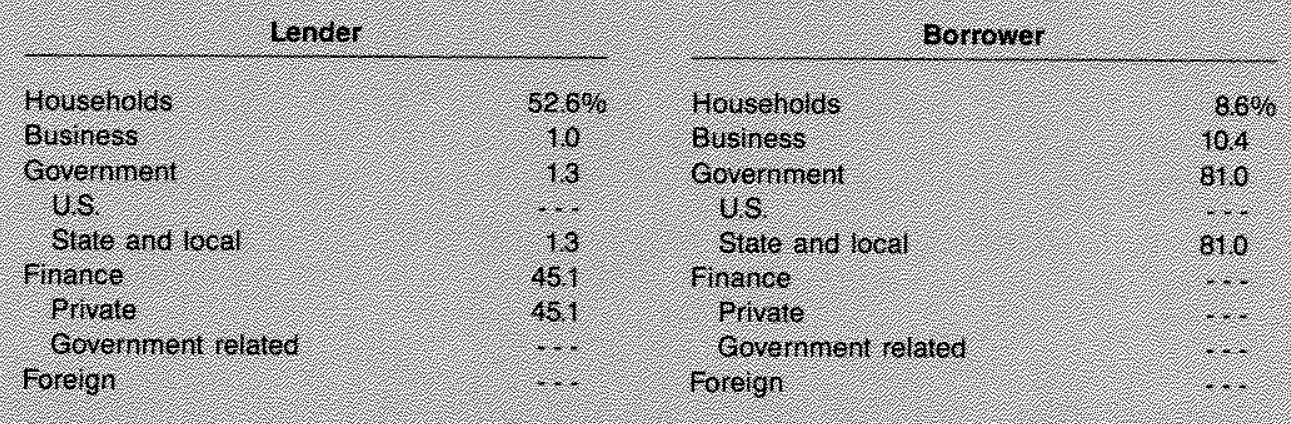


Table 1 (continued)

\section{Credit Market Debt in 1991: Who Owes and Who Owns?}

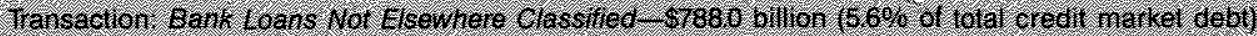

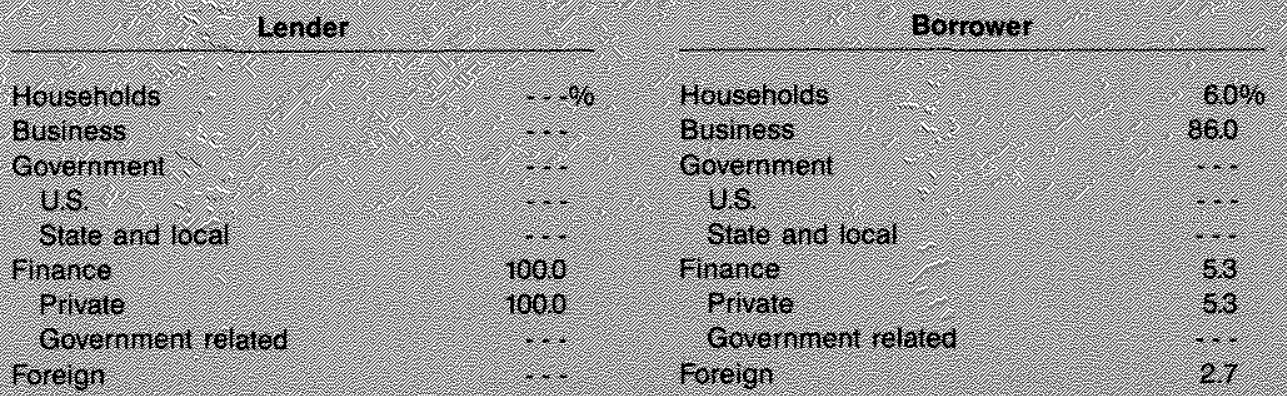

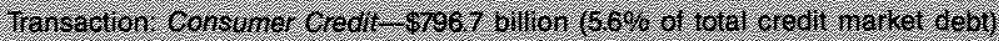

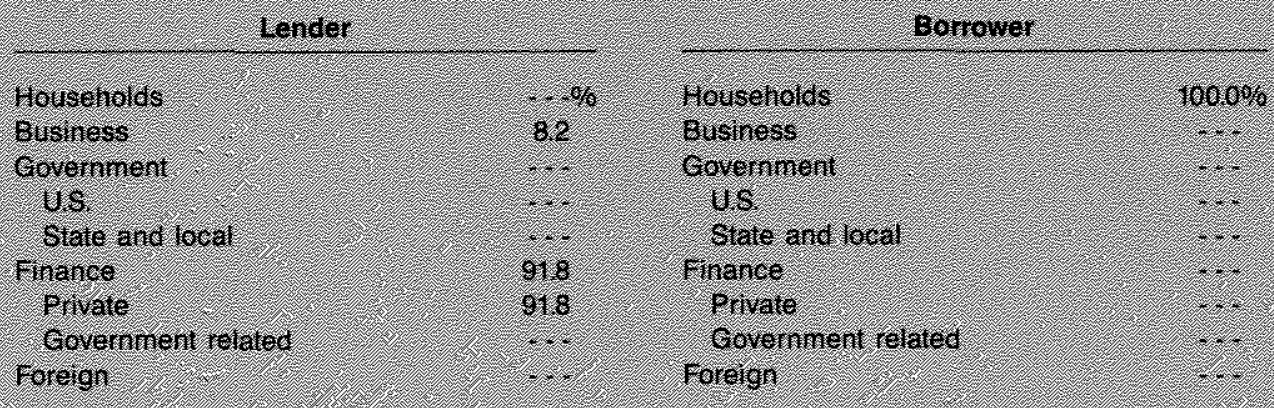

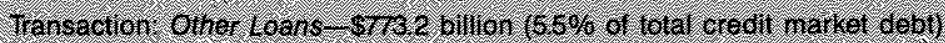

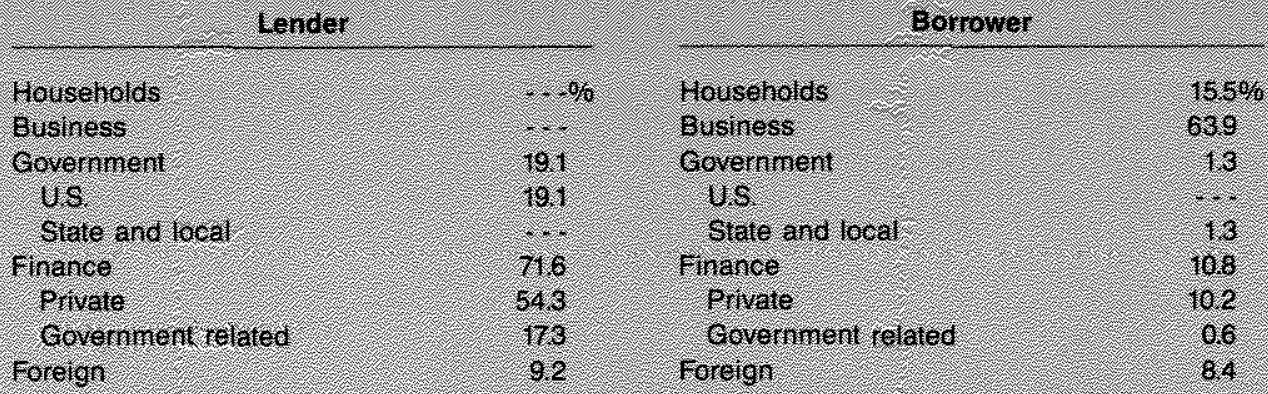

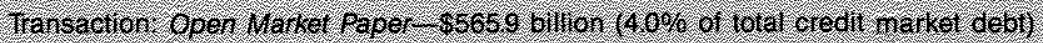

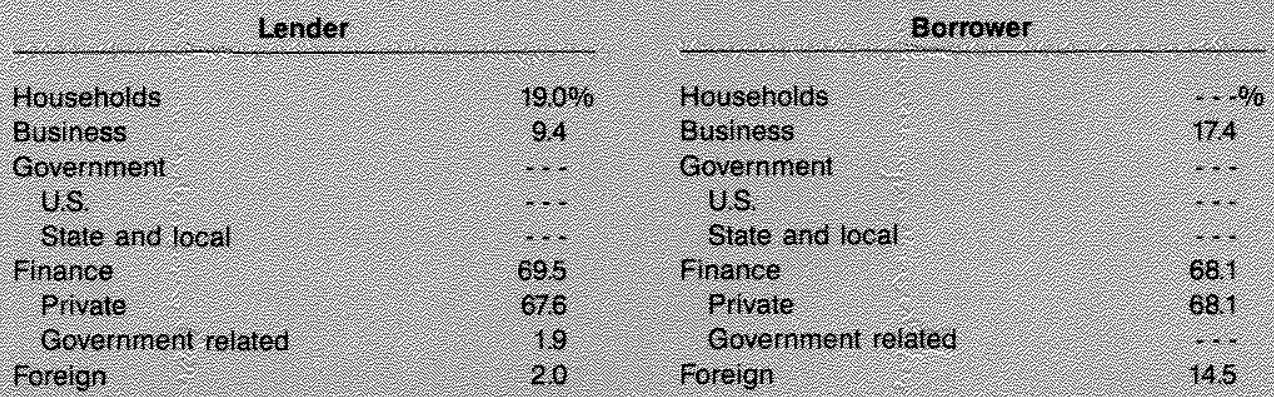




\section{The Market for Loanable Funds}

To understaind the general tole of exedit in the U.5. economy and more spectically he rale of privately owed debi, if is useful to look it the operation of 1 ie entire madket in termis of the supply and demand tor funds.

\section{The Demand for I Imds}

Honselublds constitule an importanl sector on he demand side for bredit seeking turis primarily for purchases of dumable goods. houshing und perhaps edication hituman capi 1al) Busmesses are another important bor fowing sector, Witch seeks hinds 10 issist in the purchase of plant equiment and imento: ries I Iederal, state and local governmenis also tend to demand runds because their speriding usually exceds lheir reventies. The sum of Mese sectors makes wo the nominancial denaand for funds. Finatietal instititions also de: mand finds bit lheir puppose is muly different from those of households and hust nesses. They dlemand funds to make. hem. avalable tor lowin.

\section{A drawback of looking at borrowing by} sector is that the illenification of purpose 15 not alway elear Nonetheless, his chassifica. tion is usually the basis for disccussions of debt becarse these secroms generally mateh the elassiricanions in the national incone accomits.

\section{The Supply of Funds}

To understand the market for debr fully, it is necessary to examine the lending side, that is, who made the runds avalable to he bor: rower As was the case for horrowing there is a breakdown of lending by sector:

When the lotal or credit:market debt is exa. hined in terms of the lender, it is clear that most unds are funneled hrough inancial in. lermedianies. Hie portion of credin market debt owned by financial intermediaries tpri vate tinance plus govermintrentated fimancel hus varied between 65 pertent and 75 perefont of Mie total from 1952 10 1991 . Credit market debt held by linuseholds trended dontuvard incin 22 pereent in 1952 in 12 percent in 1981 and has held steady since then An ofier sector holdingt are very small. Allough foreign holdings of ISS deht have inereased from 1 percent 11 1952 to 6 per. cent in 1991

The ultimate lenders tend io be househalds. however it is dimicult to determine what fortion of intermediaries sources of funds are liom the household sectio but in 1999 thet deposits and insurance and pension iund resermes ronstivied abour 61 pergent of total liabilites for juivate financial institilions: summary for the past three decades. Households and businesses exhibit a similar pattern in the 1970s and 1980s. During the 1960s, debt grew faster than assets for businesses but not for households. During the 1970s, debt surged, but asset values rose even faster. When the increase in asset values slowed in the 1980s, continued expansion of debt, especially in the early part of the decade, resulted in an acceleration in debt/asset ratios. In retrospect, a reaction lag of debt growth behind asset values should not have been surprising because following the rapid inflation of the late 1970 s, perceptions of low real interest rates and expectations of rapidly rising asset values were deeply entrenched. ${ }^{z}$ It appears that households and businesses reduced their expectations of inflation and scaled back their expectations of rising asset values only after inflation was reduced. These revisions eventually led to a slowing in debt growth although, on balance, debt/asset ratios rose in the $1980 \mathrm{~s}$.

Regardless of what underlies an increase in the debt/asset ratio, whether it is an explosion of debt or a fall in asset values, the chief variable under the control of the individual economic unit is debt. Indications are that businesses started to reign in debt growth by the mid-1980s. The nonfinancial corporate sector did not show signs of reducing debt growth until the late 1980s, after the period of leveraged buyouts, mergers and takeovers. Total business debt rose

${ }^{7}$ See Rutledge and Alten (1989). 
Table 2

Growth Rates of Credit Market Debt and Tangible Assets?

\begin{tabular}{|c|c|c|c|c|c|c|}
\hline & & & & & & \\
\hline Secter & Selot & Assers & Debi & Assets & Debt & Assets \\
\hline Jousehord & 119 & 610 & 930 & 18.20 & 470 & 69 \\
\hline 40517 ess & ol & 81 & 12 & 193 & 100 & 73 \\
\hline ram & -24 & 20 & 102 & 132 & 9.1 & 6 \\
\hline Hortarm hor colporate & 9 & 57 & 150 & 169 & 152 & 75 \\
\hline Montinangial corparelt & 80 & 42 & 9.5 & 673 & 90 & 60 \\
\hline
\end{tabular}

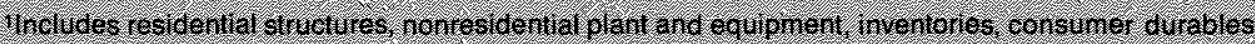
and land at markef valie.

at only a 1.1 percent annual rate from 1989 to 1991, after growing at a 10 percent rate during the previous eight years.

\section{Question 2: Are Aggregate Deb

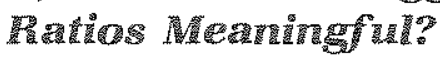

Most of the concern about debt buildup in the 1980 s stemmed from an examination of the quantity of debt relative to either GDP or the value of tangible assets. Economists have noted that it is not the quantity of debt that matters as much as the structure-who borrows what, how much and on what terms from whom. This is probably the reason that discussions of private debt are seldom found in macroeconomic texts-problems of private debt seem to be microeconomic in nature. Yet Benjamin Friedman, a Harvard economist, has found that some direct measures of financial distress-like delinquencies and business failures-seem to be correlated with movements in aggregate debt/asset ratios. ${ }^{8}$

Allan Meltzer of Carnegie Mellon University is most vocal in his skepticism about the usefulness of aggregate debt ratios, ${ }^{9}$ He stresses the uses of debt, rather than the quantity. Movements in a particular ratio do not tell whether borrowing is a reflection of profligacy or a response to an attractive investment opportunity. Furthermore, construction of such ratios is arbitrary both in terms of which economic units to include and which liabilities to define as debt. ${ }^{10}$

\section{Question 3: When Does Debt Be- come gurderis?}

Much has been made of the burden of private debt in the current recovery. Initially, there was concern that the debt buildup in the mid-1980s carried the risk of worsening the recession, if and when it occurred. When this apparently did not happen (the 1990-91 recession was relatively mild), the argument shifted to the effect of the debt load on the strength of the recovery. This view was prominent in 1991 and 1992 monetary policy reports to Congress, except that the term restructuring of balance sheets was used to describe the phenomenon.

Defining when debt becomes a burden is difficult to do. At the time the debt is incurred, it reflects conditions and expectations at that time. It can become a burden when those conditions and expectations change. Irving Fisher used the term overindebtedness, which he defined as "whatever degree of indebtedness multiplies unduly the chances of becoming insolvent ... the standards [of overindebtedness] are somewhat rough. The line of balance is more or less a twilight zone."11

To examine the conditions or factors that determine when debt seems to become a burden,

\footnotetext{
${ }^{8}$ See Friedman (1986). This will be examined in detail later. 3See Meltzer (1986).
} 
Figure 2

Private Nonfinancial Debt and Gross Domestic Product

Percent

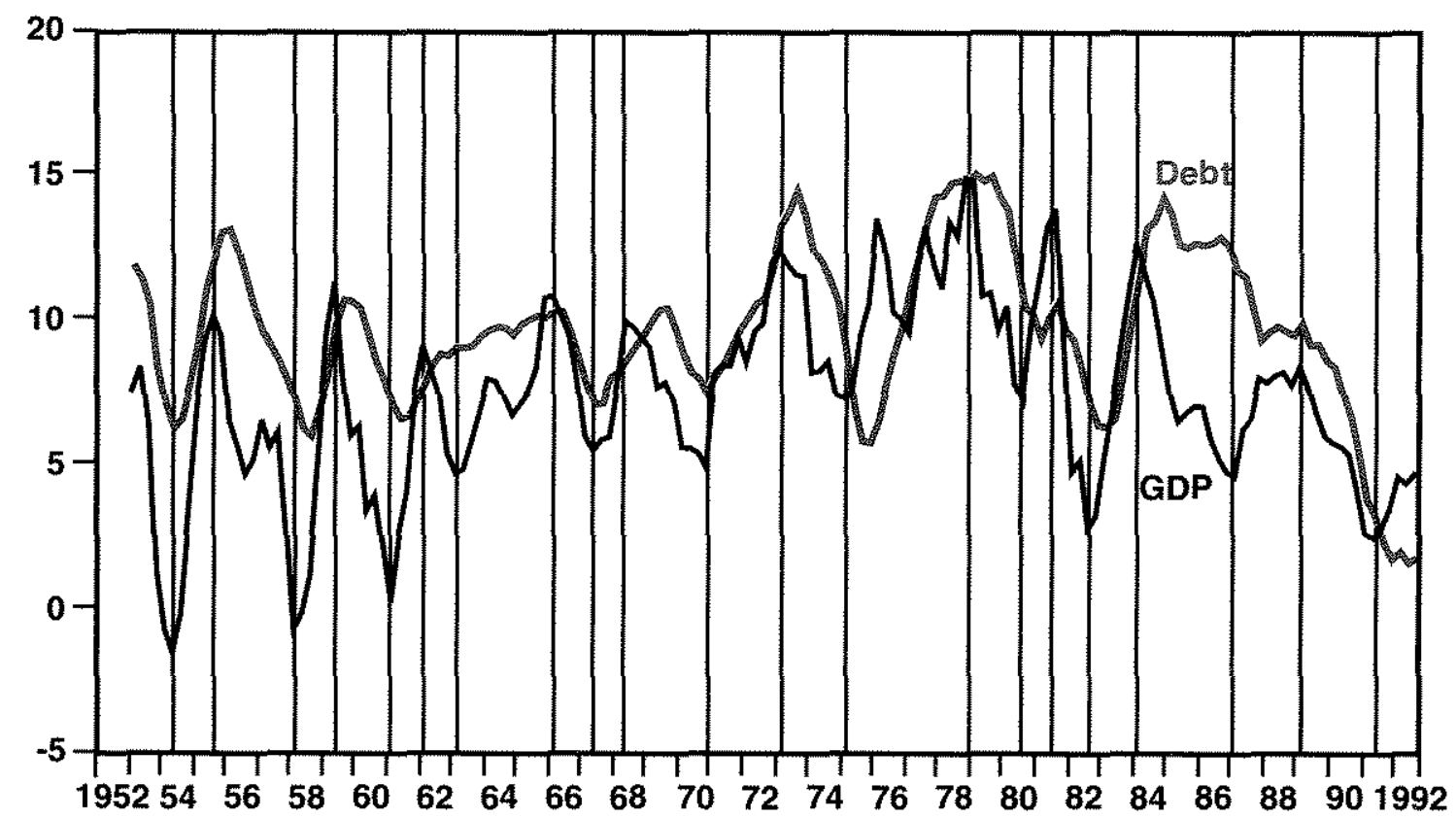

Data are four-quarter rates of change.

Vertical lines are peaks and troughs in the four-quarter GDP rates of change.

we must identify those periods when households and businesses attempt to reduce their debt growth. This does not tell us whether the debt is a burden, but it does identify periods of adjustment, or, to use the Federal Reserve's term, periods of balance sheet restructuring.

These restructuring periods are quite obvious in figure 2, which shows the fourquarter percent change in private debt and GDP. The peaks and troughs are determined visually and specifically summarized in table 3 . The pattern of GDP peaks and troughs indicates that the growth rate of output almost always peaks before debt and that debt appears to be responding to GDP rather than the other way around. Restructuring does not seem to occur until after GDP starts to fatter. This also seems to be true for troughs; GDP tends to rebound before private debt. The period since 1985 , however, is more difficult to interpret. GDP slowed after 1984, and the restructuring began simultaneously for businesses but about a year later for households. The restructuring has been going on fat different rates) since 1985 and conforms with the drop in GDP growth. In summary, the debt seems to become a burden after GDP weakens.

\section{Question 4 : Ame Corsumprion and Invesment Afected by Debt Growh?}

Although it seems clear that accelerations and decelerations of debt lag rather than lead economic activity, the question of economic effect can be approached more directly by examining household debt and personal consumption expenditures and business debt and capital expenditures.

rousehold sedor: Figure 3 shows personal consumption compared with disposable personal income and household debt compared with dis- 
Table 3

Private Debt1 and GDP: An Analysis of Leads and Lags

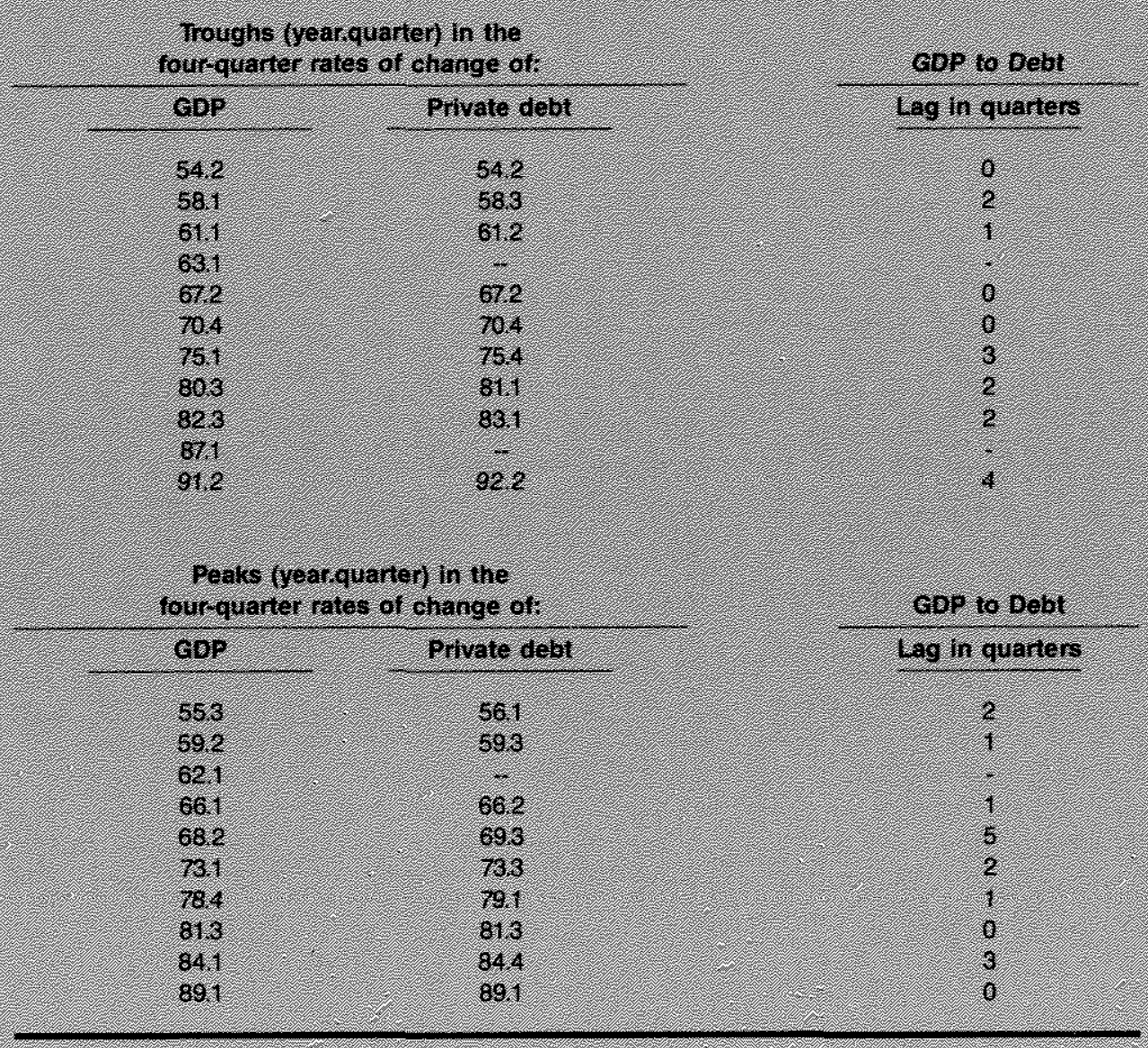

Erivate domestic noninancial dobt

posable personal income. The vertical lines correspond to recession periods. Before the $1980 \mathrm{~s}$ it is apparent that the consumption/income ratio was not systematically related to the debt/income ratio. The consumption/income ratio showed some cyclical regularities, but the debt ratio did not. On a trend basis the two ratios seemed inversely related from the early 1950 s to the mid-1960s, but the nature of the relationship isn't clear for the rest of the 1960 s and the $1970 \mathrm{~s}$.
During the $1980 \mathrm{~s}$, the two measures tended to rise and fall together, running counter to the notion that rapid debt growth inhibits consumption. As pointed out previously, consumption seems to drive debt rather than the other way around. See table $4 .^{12}$

Figure 4 shows the debt/income ratio along with delinquency rates to see whether financial difficulties for consumers are systematically related to debt growth. ${ }^{13}$ The delinquency rates for both consumer installment credit and for
12Table 4 summarizes measures of the relationship of personal consumption and household debt movements, using annual averages of the data in figure 3 . The consumption/income ratio and the debt/income ratio were negatively related during the $1953-72$ period, but this relationship was reversed from 1973-91. Because debt is a stock variable, its first difference might be viewed as more appropriate when being compared with consumption, a flow variable. On this basis, the correlation coefficient is positive for the whole period, as well as for the two subperiods. If there is a relationship between the consumption/income ratio and the debt/income ratio, it is that they tend to be positively correlated, quite the opposite of the implication of the debtburden hypothesis.

13For further discussion of these measures of payment difficuities, see Canner and Luckett (1991). 
Figure 3

Personal Consumption Expenditures and Household Debt Relative to
Disposable Personal Income

Ratio

Rasio

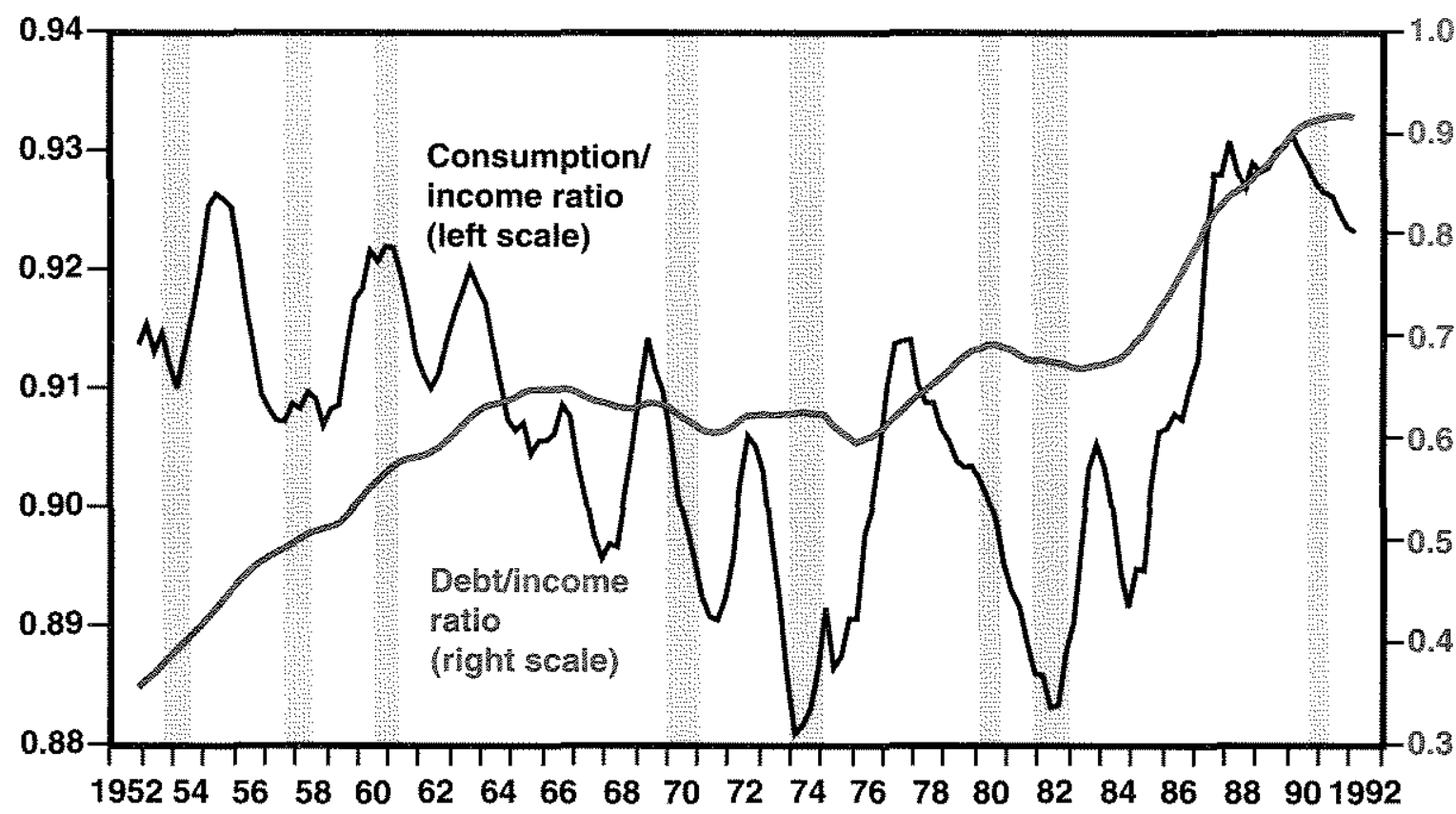

Data are centered four-quarter moving averages.

Vertical gray bars represent recessions.

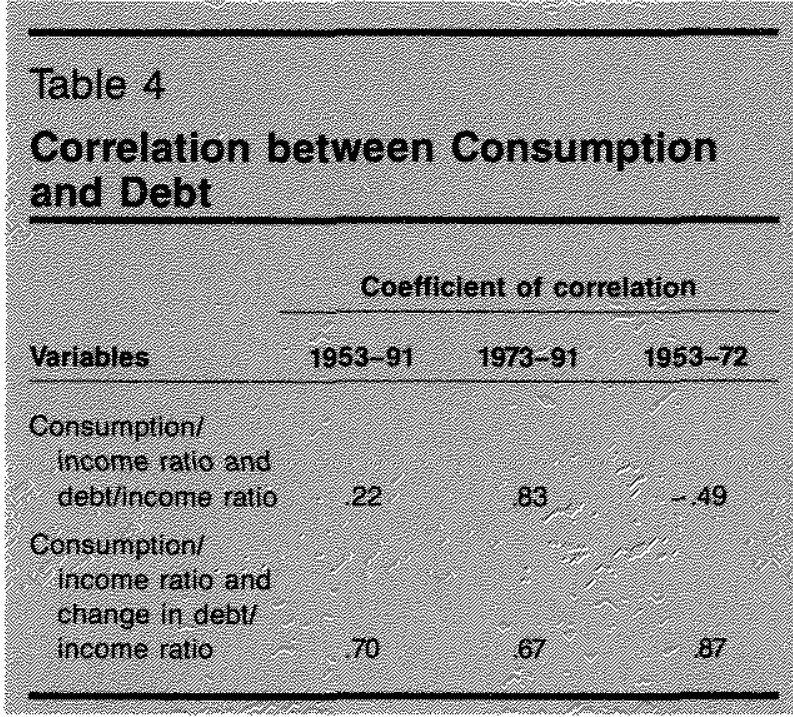

${ }^{14}$ Consumption functions have been a part of economic analysis for many years. Household debt is seldom mentioned as a determining variable, however, except to the extent that it might operate through the weaith effect as measured mortgages are responsive to the business cycle but seem to move quite independently of the debt/income ratio.

In general, the accumulation of debt by households, because it is done voluntarily, does not lead to systematic movements of consumption relative to income. Some relationship might be revealed with alternative methods of analysis, but with the graphical approach used here, there is little support for the notion that high debt ratios lead to reduced consumption relative to income. ${ }^{14}$

Pas of investment spending by businesses to gross domestic product along with the debtincome

by household net worth. See Blinder and Deaton (1985) for a suvey of time series consumption functions. 
Figure 4

\section{Delinquency Rates and Household Debt Relative to Disposable Personal Income}

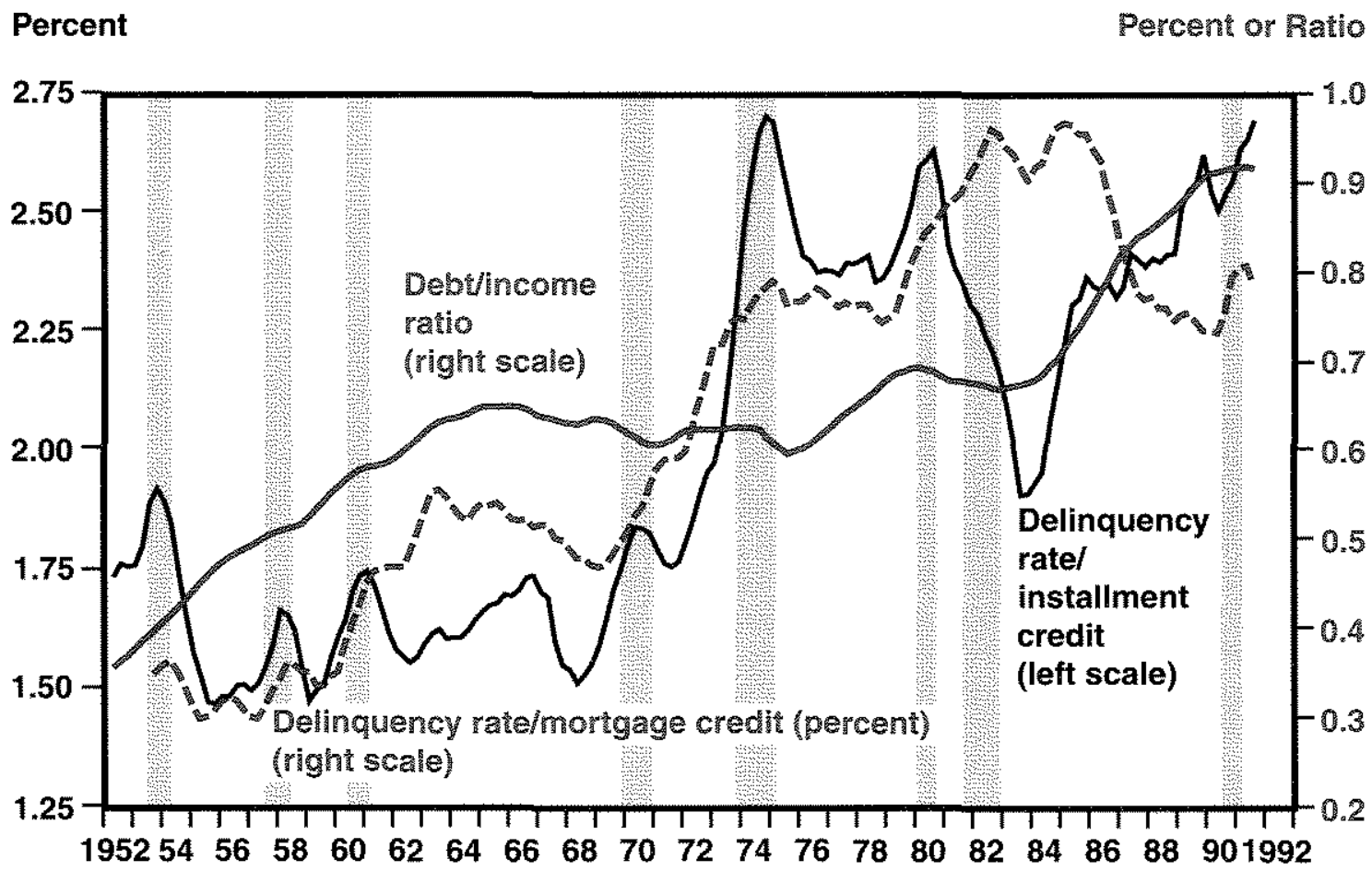

\section{Data are centered four-quarter moving averages.}

Vertical gray bars represent recessions.

ratio of the private business sector. The conclusions are somewhat the same as for households, although the two ratios move much differently. Part of the explanation might be that businesses borrow for different reasons, choosing "their financial structures to fit their plans for future expansion."15 Before the 1980s, the investment ratio showed pronounced cyclical movements about an upward trend. The debt ratio also trended upward and perhaps with some cyclical regularity, but not nearly as pronounced as for investment. During the 1980 s all signs of similar movement seemed to vanish; the debt ratio accelerated, and the investment ratio fluctuated sharply before collapsing during the second half of the decade. ${ }^{16}$ This experience would suggest that debt became a burden that contributed to a sharp decline in the investment ratio. See table $5 .{ }^{17}$

Possible concern about rising debt for the business sector involves the risk of bankruptcy. One way to look at this risk is to examine evidence on business failures. ${ }^{18}$ Figure 6 shows
15See Kopcke (1989).

16The Tax Reform Act of 1986 made interpreting the 1980 s complicated. This legisiation had the affect of discouraging investment, while at the same time providing some incentive to increase debt financing. See Slemrod (1990).

tTable 5 summarizes the relationship between investment and debt movements for the nonfinancial business sector. The correlations in table 5 confirm the results obtained from the graphical analysis. For the period as a whole, no relationship between investment and debt is apparent. The experience of the 1980s, however, suggests a negative relationship. As with consumption functions, estimated in. vestment functions generally disregard debt as a variable Only cashffow models of investment would allow for debt effects by including costs of servicing debt. For a survey of investment functions, see Kopcke (1985).

aFor a more complete analysis of business debt and the risk of bankruptcy, see Faust (1990). 
Figure 5

Investment Relative to GDP and Debt/Income Ratio for Nonfinancial Business

Ratio

Ratio

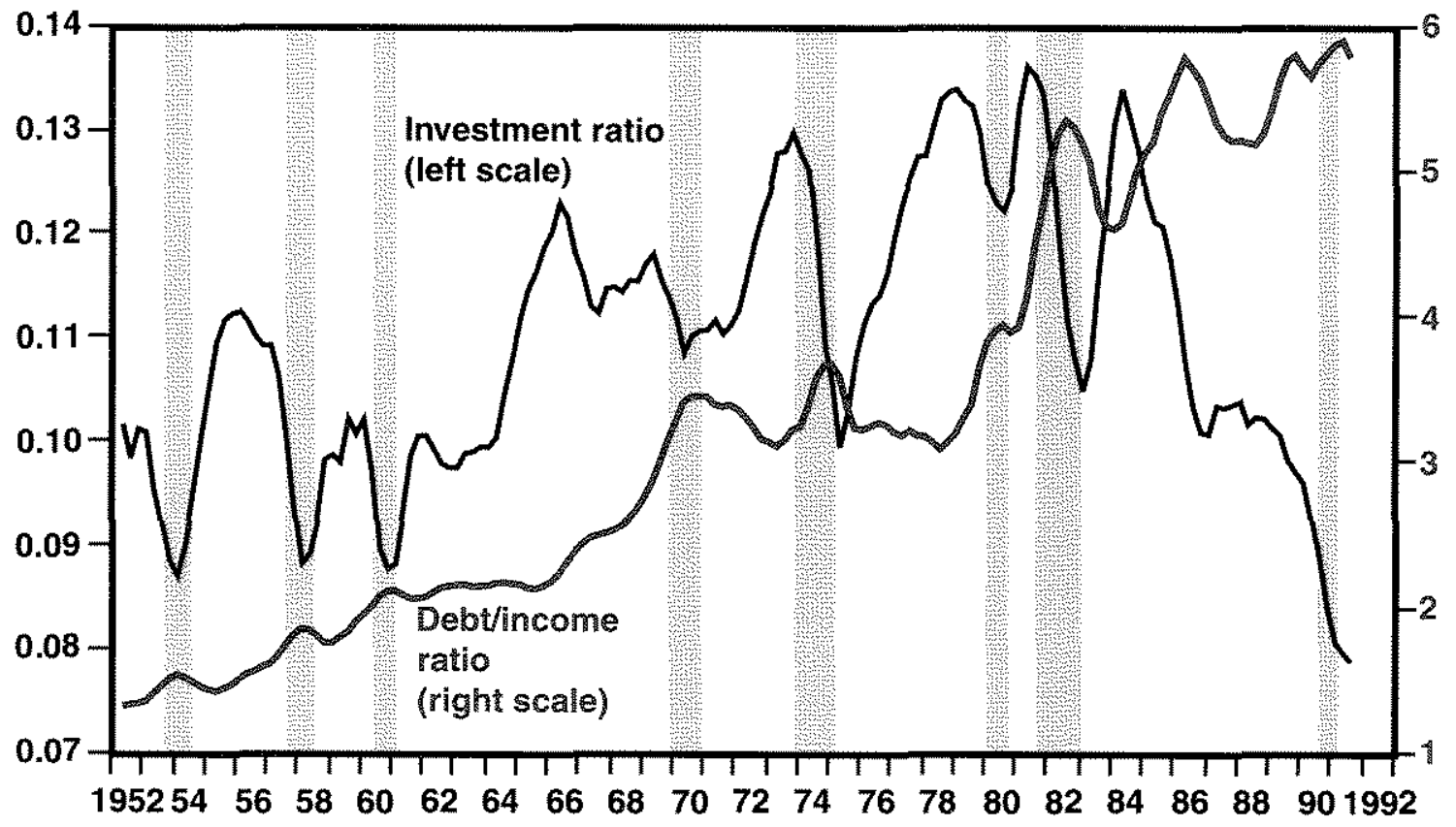

Data are centered four-quarter moving averages.

Vertical gray bars represent recessions.

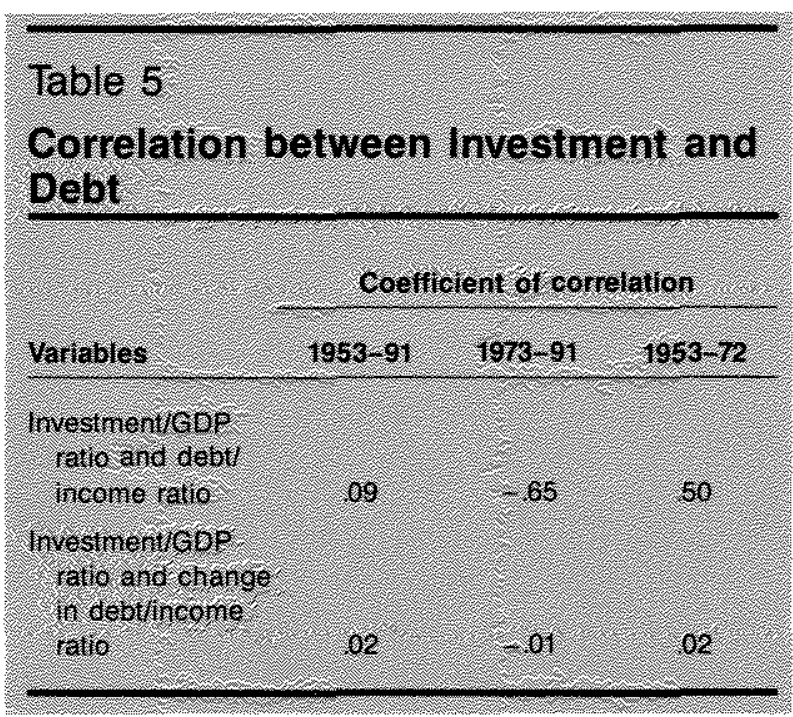

business fatlures along with the debt/ncome ratio for nonfinancial business. Before the 1980s, no relationship was apparent. During the 1980s, the two measures showed similar movement. Consequently, even though a simple graphical analysis does not reveal any systematic relationship between debt growth and investment spending during the entire period from 1952 to the present, evidence from the 1980 s supports the notion that rapid debt growth makes businesses more vulnerable to failure.

\section{GONCUSUINS}

Debt plays a key role in the functioning of a free market economy. Households, business and government all borrow and lend for a variety of reasons. Financial markets bring those holding surplus funds together with those seeking funds and allow a reallocation of funds that leads to a more efficient use of resources.

This article discussed the role of debt in the economy, focusing on private-sector borrowing. The participating sectors on both the supply and demand sides of the loanable funds market were identified, and trends in the extent of their participation were summarized. 
Figure 6

Business Failures and Debt/Income Ratio for Nonfinancial Business

$\begin{array}{ll}\text { Number Ratio } & \end{array}$

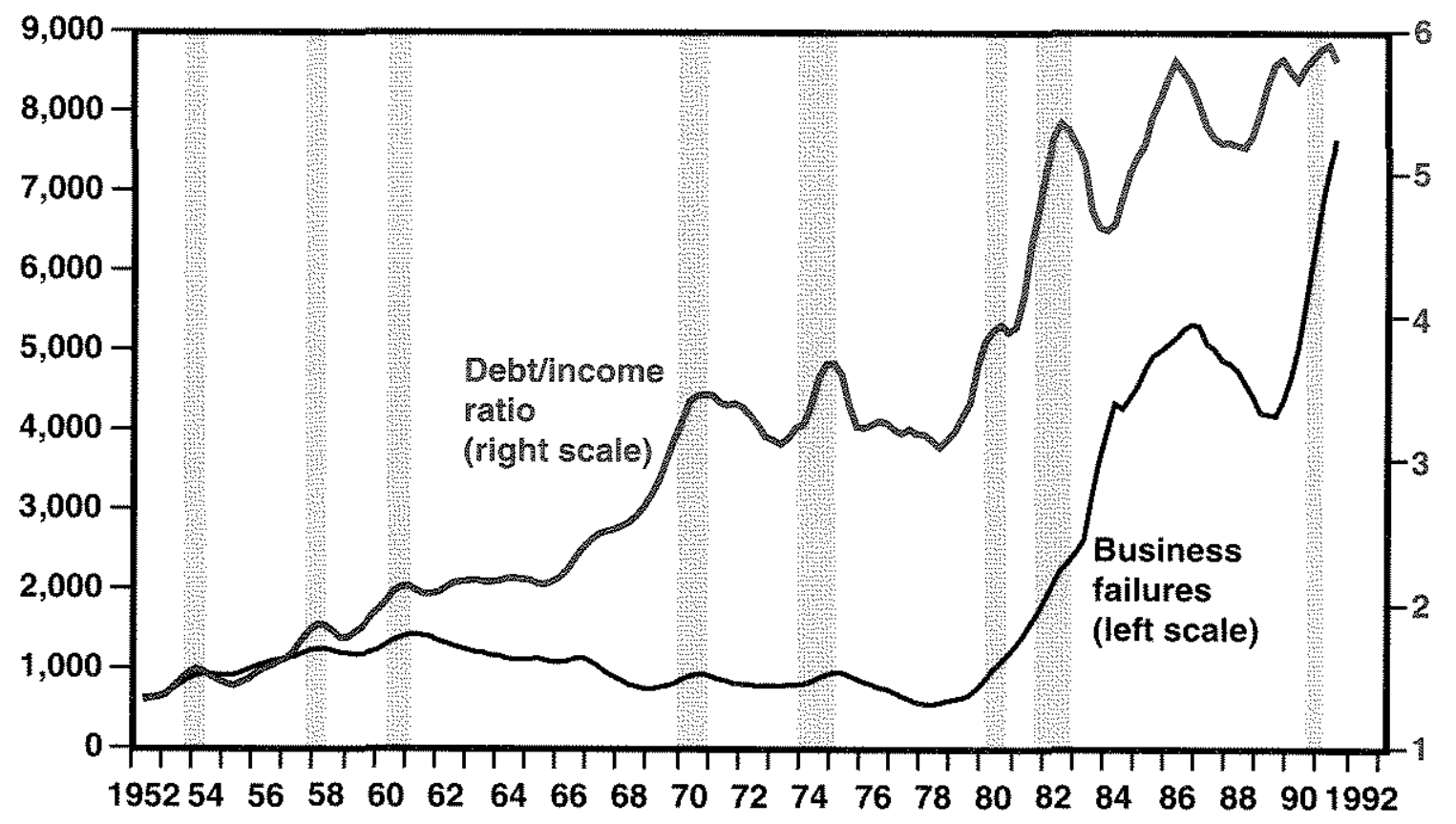

Data are centered four-quarter moving averages.

Vertical gray bars represent recessions.

Several questions relating to trends in private debt were examined. There is no doubt that private-sector debt/asset ratios have risen sharply in the 1980s. Although such ratios have their limitations, they help us understand what economic forces are at work. An examination of these debt/asset ratios indicates that the primary source of their increase in the 1980 s was the sharp deceleration in asset values. A sector-bysector analysis indicates that the private-sector groups have been slowing their borrowing for quite some time. This restructuring is well under way and is not that unusual compared with previous recessions. What is different about the current restructuring is that it also seems of a longer-term nature, representing an unwinding of the distortions resulting from inflation during the 1970s. It was that experience that contributed to a rise in debtasset ratios in the early $1980 \mathrm{~s}$ because asset values weakened when inflation was tamed by restrictive monetary policy. Debt continued to expand in the 1980 s apparently because the perception of low real interest rates carried over from the $1970 \mathrm{~s}$. In addition, it is difficult to reduce debt instantaneously even when it becomes apparent that asset values are rising more slowly (or even falling).

An examination of the movements of private debt relative to the business cycle shows that economic activity leads the debt cycle almost all of the time. 'The debt cycle is a part of the business cycle mechanism but does not appear to be a factor initiating cyclical movements. ${ }^{19}$ On the other hand, an examination of consumption and investment along with debt/income ratios did not reveal any systematic association over the last 40 years. The 1980 s stand out as unusual when viewed in a historical context. Perhaps a relationship has developed between debt and spending, but from an empirical standpoint the evidence is limited.

\footnotetext{
19See Mullineux (1990) for a survey of such theories, and also Minsky (1986).
} 


\section{REFERENCES}

Blinder, Alan S., and Angus Deaton. "The Time Series Consumption Function Revisited, Brookings Papers on Economic Activity, 2 (1985), pp. 465-52t.

Bive Chip Economic indicators (February 10, 1992).

Blyn, Martin R. "The Evolution of the U.S. Money and Capital Markets and Financial intermediaries." in Murray $E$. Polakoff, Thomas A. Durkin, and Others, Financial institutions and Markets, second edition (Houghton Miffiin, 1981), pp. $33-54$.

Canner, Glenn B., and Charies A. Luckett. "Payment of Household Debts," Federal Reserve Bulletin (April 1991), pp. 218-29.

Faust, Jon. "Will Higher Corporate Debt Worsen Future Recessions?" Federal Reserve Bank of Kansas City Economic Review (March/April 1990), pp. 19m34.

Federal Reserve Board of Governors. "Monetary Policy Report to the Congress," Federal Reserve Bulletin (April 1992), pp. 223-41.

Flow of Funds Accounts, Flows and Outstandings (September 28, 1992).

. Balance Sheets for the U.S. Economy: 1960-91 (September 28, 1992)

"Monetary Policy Report to the Congress," Federal Reserve Bulletin (March 1991), pp. 147-64.

Fisher, Irving. Booms and Depressions (Adelphi Company, 1932).

Friedman, Benjamin M. "Increasing Indebtedness and Financial Stability in the United States," in Debt, Financial Stabil- ity, and Public Policy, a Symposium sponsored by the Federal Reserve Bank of Kansas City (1986).

Greenspan, Alan. Testimony before Congress in 1992 Monetary Policy Objectives (February 19, 1992).

International Monetary Fund. "Assel Price Deflation, Balance Sheet Adjustment, and Financial Fragility" Annex 1, World Economic Outlook (October 1992).

Kopcke, Richard W. "The Roles of Debt and Equity in Financing Corporate lnvestments," Now England Economic Review (July/August 1989), pp. 25-48.

"The Determinants of Ifvestment Spending." Now England Economic Review (July/August 1985), pp. 19-35.

McCallum, Bennett T. Monetary Economics: Theory and Policy (Macmillan, 1989).

McKenzie, Richard B., and Christina Klein. "The 1980s: A Decade of Debt?" Center for the Study of American Business, Policy Study Number 114 (October 1992).

Meltzer, Allan $\mathrm{H}$. "Commentary on "Increasing Indebtedness and Financial Stability in the United States;" in Debt, Financial Stability, and Public Policy, a Symposium sponsored by the Federal Reserve Bank of Kansas City (1986).

Minsky, Hyman P. Stabilizing an Unstable Economy (Yale University Press, 1986).

Mulineux, A. W. Business Cycles and Financial Crises (The University of Michigan Press, 1990).

Rutledge, John, and Deborah Allen. Rust to Riches (Harper and Row, 1989).

Slemrod, Joel (editor). Do Taxes Matter? (MIT Press, 1990), 